\title{
Governing urban development in the Low Countries: From managerialism to entrepreneurialism and financialization
}

Paper forthcoming in: European Urban and Regional Studies

\author{
Jannes van Loon, Stijn Oosterlynck \& Manuel B. Aalbers
}

jannes.loon@gmail.com, stijn.oosterlynck@uantwerpen.be, manuel.aalbers@kuleuven.be

\begin{abstract}
Has the post-war managerial approach to urban governance in the Netherlands and Flanders been replaced by more entrepreneurial and financialized forms? In this paper, we study the transformation of urban governance in the Low Countries through city case studies of Apeldoorn (Netherlands) and Antwerp (Belgium). We show how Dutch urban governance financialized by connecting local public finance with financialized real estate markets, through municipal land banks. However, intermunicipal financial solidarity and ring-fencing municipalities from financial markets create specific, continental European processes of financialization. Flemish municipalities, in contrast, have shifted from a model of laissez-faire urban development (embedded in a system of large municipal autonomy) towards entrepreneurial urban growth regimes, in which technocratic public and private actors have increased access to public financial resources, used to create large urban renewal projects. In Belgium, autonomous municipal real estate corporations are a crucial instrument for connecting municipal finance to the real estate market.
\end{abstract}

Keywords: urban governance, financialization, entrepreneurialism, Flanders, the Netherlands 


\section{Introduction}

Since the early 1990s the governance of urban development in Europe has changed considerably: the managerial mode of urban governance is progressively being displaced by an entrepreneurial mode (Hall and Hubbard, 1996; Harvey, 1989; Lauermann, 2016). Whereas cities during the Fordist era focused on providing and managing broadly accessible urban services that are redistributive and support the economic productivity of the population, states now increasingly "bet on their strong horses" by trying to channel investments towards those urban areas that seem to have the most prosperous future, a phenomenon referred to as urban neoliberalization (Aalbers, 2013; Brenner and Theodore, 2002; Crouch and Le Galès, 2012).

More recently, urban scholars have started to discuss the emergence of financialization as a distinctive, "late-entrepreneurial" urban governance innovation (Kirkpatrick, 2016; Peck and Whiteside, 2015). Financialization refers to the "increasing dominance of financial actors, markets, practices, measurements and narratives, at various scales, resulting in a structural transformation of economies, firms (including financial institutions), states and households" (Aalbers, 2017a: 3). Financialized urbanism, then, is seen as a specific response within entrepreneurial urbanism in which forms other than those embedded in private financial practices and markets are shrinking, exhausted and out-of-reach for many cities. It leads to a situation in which "entrepreneurial strategies are increasingly realized through financially mediated means and in conjunction with credit market actors, agencies, and intermediaries" (Peck and Whiteside, 2016: 5).

Although there are many case studies on the neoliberalization of urban projects in non-Anglo-American cities (Doucet, 2013; Swyngedouw et al., 2002; Taşan-Kok, 2010) and its "financialized" forms (Guironnet et al., 2016; Halbert et al., 2014; Savini and Aalbers, 2016; Theurillat and Crevoisier, 2013), there are surprisingly few studies that analyse the rise of entrepreneurial and financialized urban governance in Europe. Therefore, this paper focuses on Dutch and Flemish municipalities to analyse if and how neoliberal forms of urban governance, specifically financialized forms, have travelled beyond the Anglo-American heartland to two continental European countries known for a strong (and corporatist) welfare state with a rich managerial tradition (Esping-Andersen, 1990). Both are densely populated countries with strong global connections, whereby economic activity is concentrated within closely connected, polycentric/network cities. The Netherlands is characterized by a pattern of relatively dense cities and hard borders between town and countryside, while Flanders is sprawled with soft borders between towns and the surrounding countryside (De Vries, 2015). Local municipal autonomy is considerably higher in Flanders, and state agencies are weaker than in the Netherlands, especially in relation to urban development (Halleux et al., 2012).

Identifying differences and similarities between the cases is important as we aim to adopt a variegated approach. Because neoliberalization processes interact with existing urban political economies and their specific development trajectories and governing configurations, they do not produce neat transitions from one form of urban governance to another, marked instead by inherently uneven and variegated processes of governance re-configuration (Brenner et al., 2010; Gonzalez and Oosterlynck, 2014); albeit on a terrain structured by the systemic tendencies of contemporary capitalism, notably financialization. Methodologically speaking, our 
approach is one of "theoretically informed, historically and geographically embedded "story-telling"' (Novy et al., 2013: 58), based on a combination of the "standard" urban studies toolbox (e.g., semi-structured, open interviews and secondary sources) and extensive financial analyses of the connections between the municipal instruments that steer urban development and general municipal finance.

In the next section we explore the characteristics of the managerial, entrepreneurial and financialized modes of governance in more detail. In the subsequent two sections, we use this framework to explore to what extent it captures recent transformations in the local governance of urban development in the Low Countries. Rather than looking at specific urban projects, we analyse the dynamics in the overall urban governance systems by focusing on municipal policy instruments, to assess if and to what extent they have evolved towards entrepreneurialism and/or financialization. Through a case study of the Dutch city of Apeldoorn, an extreme but not exceptional case, we show how Dutch municipalities adopted pro-growth policies and connected themselves to a financialized real estate market through active land banking. The case study of the Flemish city of Antwerp, which epitomizes the shift to urban entrepreneurialism in Flanders, shows a slow turn towards a more hybrid form of urban entrepreneurialism, in which local political conditions partially offset some of the neoliberalizing tendencies (with underlying entrepreneurialism and largely absent financialized practices). In the conclusion, we reflect on the uncovered insights for the variegated reproduction of more marketoriented municipal instruments to steer urban development.

\section{Modes of urban governance}

Under managerial urban governance the local state manages "the city through bureaucratic means" (Hall and Hubbard, 1996: 154), aiming to support the reproduction of labour through public service delivery (Harvey, 1978, 1989). In the post-WWII period relatively strong, centrally led states adopted policies of spatial Keynesianism, in order to spread geographically the wealth through redistributive systems and urban/regional policies, combined with national legislation developed in a top-down technocratic manner (Brenner, 2004; Savitch and Kantor, 2002). Public service policies were designed by the national government, but executed by stable local political coalitions (Hall and Hubbard, 1996; Harvey, 1989).

Neoliberalism as an "explicit political-economic project" (Peck and Tickell, 2002 , p. 384) was established during the 1980 s by a "rolling back" of these welfare arrangements. In the 1990s neoliberalism has been "rolled out" through re-scaling and re-configuring state agencies and institutions prioritizing commodification, marketization, and privatization (Peck, 2004). National states have shifted from a focus on service provision and welfare distribution towards neoliberal modes that prioritize wealth creation through competition on multiple scales for investment, economic activity, tourists and the economic sustainable population, thereby betting on their "strong horses", often their "champion cities" (Harvey, 1989; Crouch and Le Galès, 2012; Brenner, 2004).

Accordingly, over the past decades, managerial urban governance is increasingly being superseded by entrepreneurialism (Lauermann, 2016). In the context of globalization, the downscaling of governmental responsibilities and a general re-commodification of welfare (Brenner, 2004; Swyngedouw et al., 2002), 
municipalities acquired increasing financial and fiscal autonomy and allegedly shifted their priorities from welfare distribution to wealth creation, thereby fostering cooperation with private actors and prioritizing market-oriented strategies. The perceived increase of intra-urban competition is met with a pro-growth agenda that prioritizes prestigious real estate projects that "put the city on the map". Consequently, hierarchies of place are introduced, prioritizing areas that are perceived as contributing the most to urban competitiveness (Aalbers, 2017b). Politically, decision-making processes have moved largely into "the 'in-between' spaces of governance that exist outside, alongside or in-between the formal statutory scales of government, from area masterplans to multiregional growth strategies" (Haughton et al., 2013: 220), where private and public technocrats operate outside democratic control (Oosterlynck and Swyngedouw, 2010; Swyngedouw, 2009).

In the United States, the financialization of urban governance is conceptualized as an embedding of the "new" entrepreneurial local spirit into deep, global financial markets. Structural supra-municipal budget cuts have increased the impetus for urban entrepreneurialism, while dependence on both local taxes and external finance has become increasingly speculative and predatory (Kirkpatrick, 2016; Peck and Whiteside, 2016). Municipal budgets increasingly rely on creative financial engineering, for instance by monetizing future tax-income from urban redevelopment and infrastructure (Weber, 2010). Consequently, as cities financialize their public assets, the provision of urban services has become increasingly entangled with financial capital through various opaque institutional arrangements (Ashton et al., 2016). In addition, conservative external finance started to morph into increasingly complex forms of municipal debt financing through opaque vehicles that place municipal finance largely outside democratic control (Kirkpatrick, 2016). This "process of systematic financial intensification" (Peck and Whiteside, 2016: 27) has made financial logics dominant in US urban governance by closely interweaving urban futures and current policy possibilities with financial markets' volatility and financial orthodoxies, without providing any protective layers of government. In other words, to a certain extent, finance now governs American cities.

This US-focused account of shifts in the governance of urban development needs to be critically examined within the European context. There is extensive literature on how urban planning in Europe has transformed from the provision of a public good towards enabling "markets" to take the lead in producing the built environment (Haughton et al., 2013; Pinson and Morel, 2016). Others have illustrated how urban re/development projects increasingly aim to satisfy the desires of financial investors (Guironnet et al., 2016; Theurillat and Crevoisier, 2013). Yet, comparative studies of the contemporary reconfiguration of urban governance in Europe are lacking. After a brief discussion of the research methodology, we will analyse the reconfiguration of urban governance in two cities in continental, corporatist welfare states, in the Netherlands and Flanders (Belgium), and assess whether the notions of entrepreneurial and financialized urban governance adequately capture these processes of local governance reconfiguration.

\section{Research methodology}

As discussed above, it is expected that processes of neoliberalization first stimulated a more entrepreneurial stance towards urban development and later opened it up to financialization practices. This shift is most visible at the municipal level, because 
decisions that shape urban development are made and local budgets are managed at this level. However, local decision-making and budgeting are complex, messy and highly technical processes, making it hard to assess the neoliberalization of urban (re-)development (Gerring, 2007; Le Galès, 2016). The existence of multi-scalar governance further increased the complexity of the system, by shaping the municipality's "manoeuvring space" (Cox, 2010; Oosterlynck, 2010; Savitch and Kantor, 2002)

To unravel this complexity, this paper sets out to analyse what types of wider processes and changes set in motion the financialization/entrepreneuralization of urban government. The case study selection is inspired by recent theorizing in comparative urban studies (Robinson, 2015; Flyvbjerg, 2006) that does not prioritize the comparability of cities in search for "the symptoms of a problem" (Flyvbjerg, 2006 , p. 229) but rather looks at "how a specific urban outcome emerges, and through this engagement with its production, or genesis, alongside many other interrelated phenomena, to draw it into conceptualization" (Robinson, 2015, p. 18). We focus on one Dutch and one Flemish municipality - Apeldoorn and Antwerp respectively - to trace the genesis of processes of financialization and entrepreneuralization, by scrutinizing how municipal tools that are used to steer urban development connect municipal finance with local real estate markets. In this respect, analyses of the instruments used to steer local urban development (through land banks and an autonomous real estate corporation), are crucial to show how municipal finance became connected to local real estate markets. As the use of these instruments is widespread in the Low Countries, the study's findings can inform research of other municipalities. In addition, the cases offer insights on the variegated reproduction of more market-oriented municipal instruments to steer urban development.

This perspective enables us to study variegation through "theoretically informed, historically and geographically embedded 'story-telling'" (Novy et al., 2013, p. 58), and by bringing the cases into "creative conversation" (Springer, 2012) with the wider (Anglo-American) literature. A wide range of research methods was used in both cases, including semi-structured, open interviews (six interviews with six people in Antwerp, three interviews with six people in Apeldoorn - see Appendix I), annual reports from both municipalities and AG Vespa (including archival research), policy documents (including many documents on urban planning), media reports as well as internal and external research reports (see Van Loon, 2017 for a more detailed overview). The various sources were typically used together; for instance, media reports helped to prepare interviews, and annual reports and policy documents helped to verify interview data.

However, as each context demands its own research tactics (Sassen, 2013), the methods were applied differently in each case. For instance, the financial dimension of Dutch urban development has been analysed by a wide variety of independent research institutions, due to the large losses of municipal land banks. These reports were very useful to better understand the Apeldoorn case and reduced the need for direct interviews with financial experts. For Antwerp, on the other hand, there is not much publicly available data. Therefore, interviews, analyses of the annual reports and archival research played a more important role in this case. Nevertheless, analysing both cases through similar methodological anchors enables a comparison via reflection on the uncovered similarities and differences (cf. Novy et al., 2013; Van Loon, 2017). 
Table X Crucial dimensions of managerial, entrepreneurial and financialized modes of urban governance (not published in final version)

\begin{tabular}{|c|c|c|c|}
\hline & $\begin{array}{l}\text { Managerial Urban } \\
\text { Government }\end{array}$ & $\begin{array}{l}\text { Entrepreneurial Urban } \\
\text { Governance }\end{array}$ & $\begin{array}{l}\text { Financialized Urban } \\
\text { Governance }\end{array}$ \\
\hline $\begin{array}{l}\text { 1)Domestic } \\
\text { political } \\
\text { economy }\end{array}$ & $\begin{array}{l}\text { Fordist; steady } \\
\text { economic and } \\
\text { income growth; } \\
\text { politics of income } \\
\text { redistribution }\end{array}$ & $\begin{array}{l}\text { "After-Fordistflexibilization and } \\
\text { internationalization; weak and } \\
\text { uneven growth; deflating } \\
\text { downtown property markets" } \\
(\mathrm{P \& W})\end{array}$ & $\begin{array}{l}\text { "Speculative and predatory } \\
\text { finance; credit market } \\
\text { instability; low growth and } \\
\text { precarity; real estate bubbles" } \\
\text { (P\&W) }\end{array}$ \\
\hline $\begin{array}{l}\text { 2)Inter- } \\
\text { governmental: } \\
\text { financial }\end{array}$ & $\begin{array}{l}\text { Comprehensive } \\
\text { federal/central state } \\
\text { redistributive grand- } \\
\text { systems to provide } \\
\text { local public services; } \\
\text { large bureaucracies }\end{array}$ & $\begin{array}{l}\text { increased financial and fiscal } \\
\text { municipal autonomy; } \\
\text { restructuring of subsidies } \\
\text { towards 'competitive' projects; } \\
\text { less countercyclical budgeting }\end{array}$ & $\begin{array}{l}\text { "procyclical budgeting; systemic } \\
\text { public sector austerity" (P\&W) }\end{array}$ \\
\hline $\begin{array}{l}\text { 3)Inter- } \\
\text { governmental } \\
\text { planning/ } \\
\text { urban policy }\end{array}$ & $\begin{array}{l}\text { Strong role } \\
\text { federal/central state } \\
\text { agencies; social } \\
\text { housing; planning for } \\
\text { public goods' and } \\
\text { sectoral (economic) } \\
\text { goals }\end{array}$ & $\begin{array}{l}\text { Prioritizing entrepreneurial } \\
\text { activities; reregulating to } \\
\text { facilitate more market } \\
\text { oriented 'soft' or 'flexible' } \\
\text { planning and empowering } \\
\text { local private actors/(semi- } \\
\text { )public agencies }\end{array}$ & $\begin{array}{l}\text { More market oriented, opening } \\
\text { the built environment up for } \\
\text { financialization processes }\end{array}$ \\
\hline 4)Regulation & $\begin{array}{l}\text { Clear national } \\
\text { legislation }\end{array}$ & $\begin{array}{l}\text { "After the fact, by interurban } \\
\text { competition" (P\&W): EU 'free } \\
\text { market' rules }\end{array}$ & $\begin{array}{l}\text { Increasingly in favour of wishes } \\
\text { financial actors (i.e. borrowers } \\
\text { and investors)? }\end{array}$ \\
\hline $\begin{array}{l}\text { 5)Governing } \\
\text { Rationalities }\end{array}$ & $\begin{array}{l}\text { Social reproduction } \\
\text { and protection for } \\
\text { (lower)middle class }\end{array}$ & $\begin{array}{l}\text { "'Growth machine' consensus; } \\
\text { task-focused rationalities } \\
\text { development coalitions; rentier } \\
\text { class and exchange-value } \\
\text { driven; publicly subsidized } \\
\text { development with risk-averse } \\
\text { partners; speculative } \\
\text { construction of place" (P\&W) }\end{array}$ & $\begin{array}{l}\text { Increased municipal financial } \\
\text { creativity/risk taking? } \\
\text { Reregulation opening } \\
\text { municipalities up for } \\
\text { financialisation processes? }\end{array}$ \\
\hline 6)Techniques & $\begin{array}{l}\text { State develops real } \\
\text { estate for public } \\
\text { good provision; state } \\
\text { funding for } \\
\text { properties housing } \\
\text { economic activity }\end{array}$ & $\begin{array}{l}\text { "Corporate subsidization and } \\
\text { place marketing; experimental } \\
\text { privatization; enterprise zoning } \\
\text { and deregulation" (P\&W); PPP }\end{array}$ & $\begin{array}{l}\text { Creative ways to adopt } \\
\text { financialisation techniques and } \\
\text { tools? (in)directly connected to } \\
\text { financialisation through close } \\
\text { corporation with financialized } \\
\text { actors and financialized real } \\
\text { estate markets? }\end{array}$ \\
\hline $\begin{array}{l}\text { 7)Political } \\
\text { dynamics }\end{array}$ & $\begin{array}{l}\text { Stable political } \\
\text { coalitions; 'machine' } \\
\text { politics }\end{array}$ & $\begin{array}{l}\text { "growth coalitions, democratic } \\
\text { deficits" (P\&W) }\end{array}$ & $\begin{array}{l}\text { Transforming into } \\
\text { "Postdemocratic technocracy: } \\
\text { emergency management, } \\
\text { budgetary fiat, fiscal } \\
\text { balkanization" (P\&W)? }\end{array}$ \\
\hline
\end{tabular}

Sources: mostly based on Peck and Whiteside (2016, p.6) (P\&W), and section 2 of chapter 5.

Grey (1-4): Factors/processes that can give rise to managerial/entrepreneurial/financialized urban governance

Non-grey (5-7): main characteristics of managerial/entrepreneurial/financialized urban governance 


\section{The Netherlands: Connecting municipal finance to financialized real estate markets}

\section{The public land development model}

As a country with a long history of creating collective water protection systems, the Netherlands has a strong tradition in urban planning and urban policymaking. Indeed, the local governance of urban development could be considered a textbook case of the managerial model. Strong fiscal centralization and a central state providing local services have created strong "interdependencies between cities and the central state" (Uitermark, 2005: 155). In the 1980s, urban policy aimed at furthering "compact cities" through restrictive planning and urban renewal projects, with co-governance between municipality, province and central state. In addition, massive public investments flowed into construction of affordable housing (TaşanKok and Korthals Altes, 2012).

In the Public Land Development model (hereafter PLD) planners from the central state decided where and what to build, while the municipality bought and rezoned the land, readjusted parcels and sold them to developers (Halleux et al., 2012). Municipalities were financed by state banks and could use eminent domain to acquire land. Through municipal land banks (grondbedrijf) - administrative and/or organizational entities that manage the municipality's land activities (Enquetecommissie Grondbedrijf, 2012: 71) - land could be acquired at relatively low prices. As the difference between cost price and market value of construction sites was typically small, private developers did not challenge this model - their profits were realized in construction (Van Der Krabben and Jacobs, 2013). As long as projects were profitable, municipalities recovered the public works costs, including social housing, thus fulfilling the double role of planning agency and land investor.

During the 1990s urban planning responsibilities were decentralized to semipublic institutions such as housing associations, but also to provinces and municipalities, as increasing competitiveness became a key urban planning objective (Hajer and Zonneveld, 2000). Waves of privatization and reregulation set in motion a debt-fuelled real estate boom (Aalbers, 2012; Taşan-Kok, 2010; Van Loon, 2016), and PLD increasingly facilitated the interests of a loose coalition of real estate developers, banks and municipalities (Buitelaar and Bregman, 2016; JanssenJansen et al., 2012).

To finance pro-growth ambitions, typically based on real estate and infrastructure projects, municipalities tried to increase the revenue streams that they could autonomously spend. The most sizeable - and easiest to manipulate revenue stream comes from land banking. In 2010 all Dutch municipalities together owned developable land valued at EUR 12.7 billion (RFV, 2015). Land had become increasingly lucrative as continuously rising real estate values increased development margins (Buitelaar and Bregman, 2016; Janssen-Jansen et al., 2012). In the 1990s private developers started to contest the eminent domain power of municipalities, which, strictly legally speaking, is only valid when the landowner is not able to undertake development according to zoning regulations. New national planning policy (known as VINEX) intentionally restricted new developments to specific areas, thereby enabling municipalities to extract higher land gains, which 
could be used to develop better infrastructure. However, developers started to buy large plots of, often rural, land, which they then sold to municipalities at

a price similar to their costs in acquiring it. The municipalities continued with their role as public land developers and sold, after servicing the land, building sites against full market value to the same commercial developers. (Van Der Krabben and Jacobs, 2013: 780)

The new way of developing required municipalities and developers to build longterm relationships; some municipalities started informing preferred developers so they could protect land "from being snapped up by 'hostile invaders"' (Taşan-Kok and Korthals Altes, 2012: 1275).

To stimulate development, municipalities and provinces used very ambitious future scenarios, thus creating a model of "over-optimistic over-zoning" (JanssenJansen et al., 2012: 2). As long as real estate prices increased, this model worked well and produced high-quality built environments where profits were shared between public and private actors (Taşan-Kok, 2010; Doucet, 2013). Municipal development gains subsidized non-profitable investments such as affordable housing, but in the boom years 2004-2008 an estimated EUR 3.2 billion also went into new prestige constructions (RFV, 2015). Excessive debt generation masked the fact that the real population and economic growth were not strong enough to sustain the fictitious real estate values (Janssen-Jansen et al., 2012; Van Loon, 2016). When in 2009 the crisis hit, municipalities discovered that their building claim contracts with developers did not impose a time limit on the retransfer of the developable land to developers, who therefore waited it out. Undeveloped land held by land banks resulted in EUR 3.3 billion in municipal losses between 2009 and 2013. As a result a number of municipalities, including Apeldoorn, were placed under special supervision and forced to take severe austerity measures (RFV, 2015).

\section{Apeldoorn's Municipal Land Bank}

The core of the problem is a too ambitious municipal growth-target that was translated into large municipal land purchases. The possible profits from these land activities were estimated unrealistically high and never adjusted properly. (Enquetecommissie Grondbedrijf, 2012, p. 44 translated by authors)

Apeldoorn, the $11^{\text {th }}$ largest city in the Netherlands with a population of approximately 160,000 , is an extreme case of municipal land banking and risk-taking. It is, however, not an exceptional case since many municipalities used their land banks in similar ways to get involved in "active land use policies" to support aggressive progrowth policies (cf. Janssen-Jansen et al., 2012). At the dawn of the $21^{\text {st }}$ century the Apeldoorn formulated strong pro-growth ambitions. It adopted a bright view of the future, stipulated in the vision "Apeldoorn 2020", setting out to improve the city's green areas, conditions for living, working and leisure, thereby emphasizing Apeldoorn's green urbanity and central location within the country. This municipal entrepreneurial vision defined the city as a key regional area where future demographic and economic growth would be concentrated. Based on an optimistic scenario, Apeldoorn calculated high demand for business parks, offices $\left(320,000 \mathrm{~m}^{2}\right)$ and residential units (see table 1A.1/1A.3) (Gemeente Apeldoorn, 2001). 


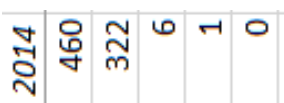

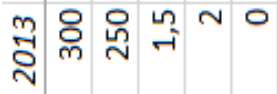

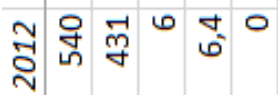

ปั่

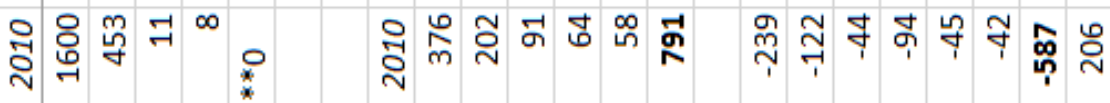

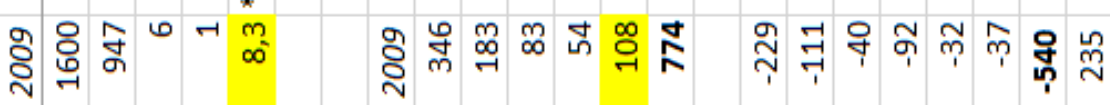

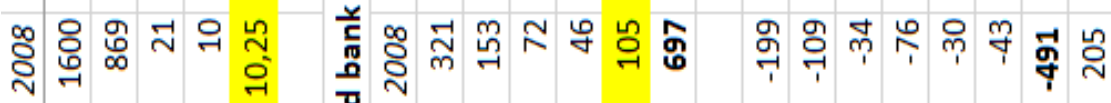

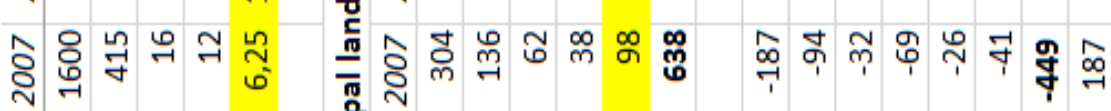

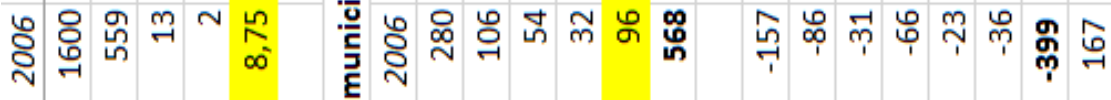

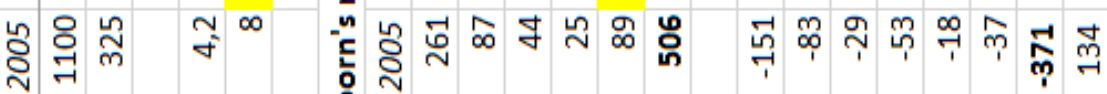

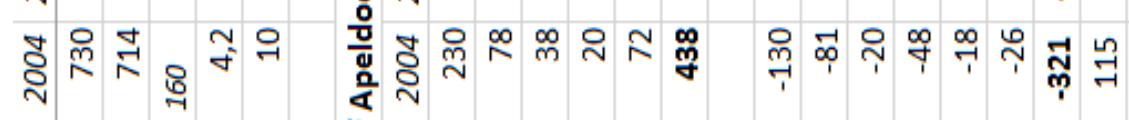

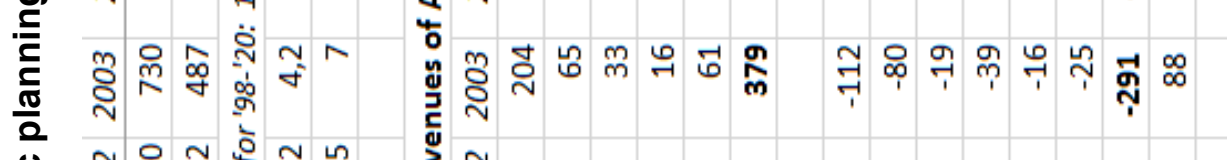

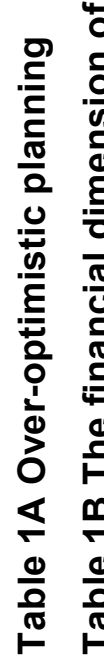

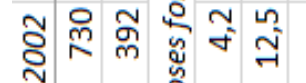

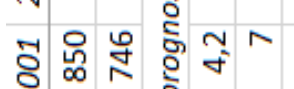

ำ

จ

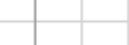

$$
\text { 政 }
$$

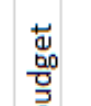

|ct

䓂

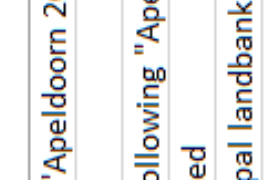

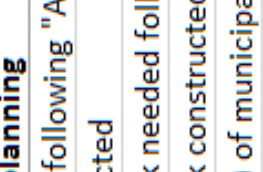

웜

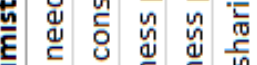

흥

就 $\frac{5}{\mathrm{~N}}$

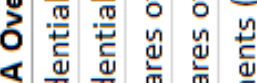

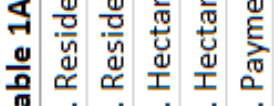

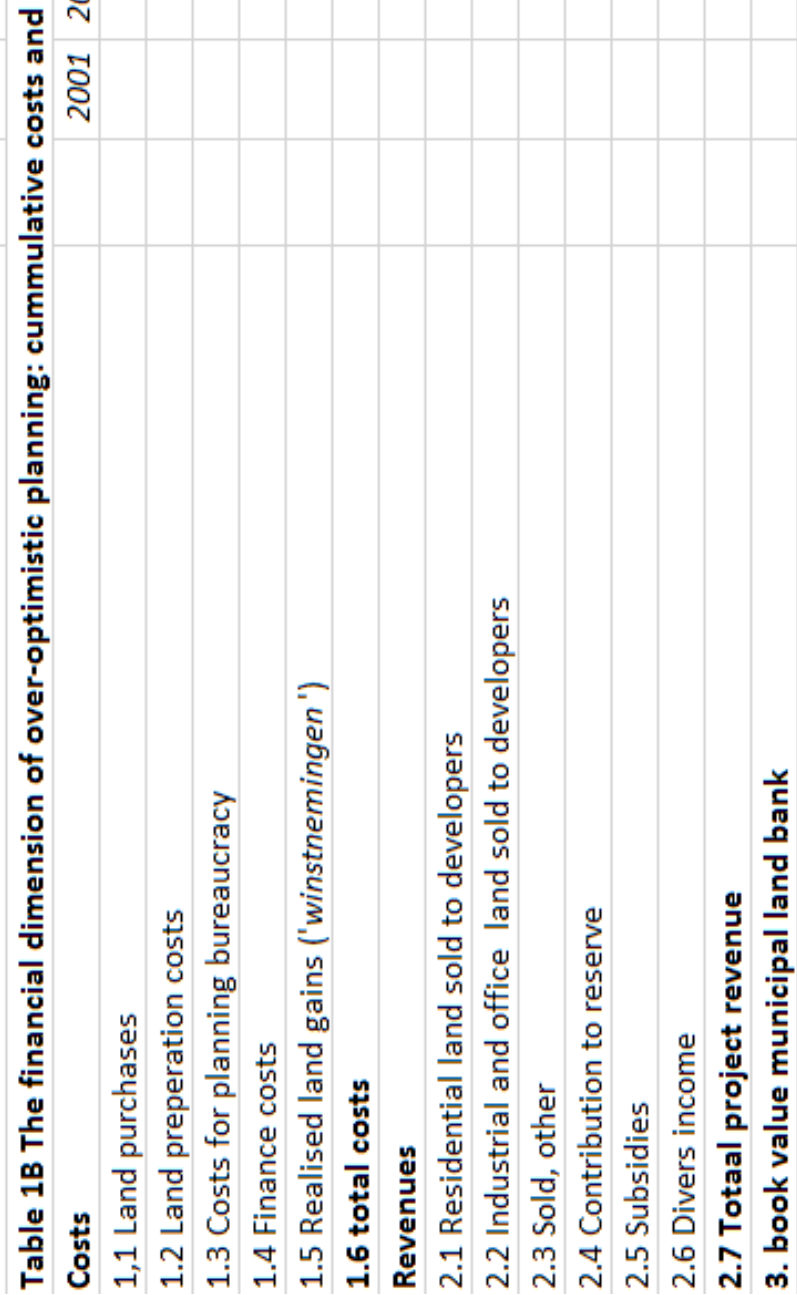

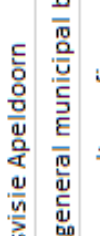

م 
The Municipal Land Bank was the key organization to realize these growth ambitions and capture land value increases. Apeldoorn's Urban Planning Department, in line with the practices of many other Dutch municipalities at the time (Buitelaar and Bregman, 2016; RFV, 2015), not only advised the city on planning affairs but also was responsible for achieving land gains through buying and selling developable land. The Land Bank is the entity through which the trades are administrated. Organizationally, it is a loose gathering of different project administrations; civil servants did not work directly for the Land Bank. This loose organizational structure combined with bureaucratic calculative practices functioned as "a commercial entity within a public house ... that became increasingly dis-embedded from the regular bureaucratic organization" (Interview 7) and enabled over-optimistic growth ambitions to grow into excessive risk-taking through large municipal investments into land.

The land banking and development activities of Apeldoorn could be characterized by unprofessional land acquisition, unrealistic accounting and the neglect of risks (for details, see Van Loon, 2017). In addition, the Land Bank never increased its buffer of EUR 11.3 million, despite increasing its land holdings from EUR 88 million in 1999 to EUR 235 million in 2009. Aware of the profitable investments of the Land Bank, the Municipal Executive Board in 2006 started to demand a minimum annual income from the Land Bank to fund the entrepreneurial ambitions of its political programme of 2006-2010 (see table 1A.5). As general central government funding was labelled for the provision of local public services, the additional income from the Municipal Land Bank could be used to fund more entrepreneurial plans, such as municipal real estate projects like an indoor cycling stadium for international matches. Dissenting voices were ignored and the City Council did not investigate the land activities critically as it shared the Municipal Executive Board's optimism and entrepreneurial ambitions.

The City of Apeldoorn thus inflated a land development bubble that did not express developers' willingness to buy land but rather overly optimistic and risky municipal visions and calculative practices. Combined with the increasing debt of the City as a result of executing other expensive municipal real estate projects (sports arena, a museum, new schools), it brought the City to its knees when in 2010 the Province of Gelderland forced the Municipal Executive Board to adopt more realistic zoning plans. Severely lowering the planning capacity meant that estimated future profits became losses. This devaluation of municipal land holdings and non-developed land is clearly observable in Figure 1, dropping from EUR 293 million in 2009 to EUR 115 million in 2011. This tipped the municipal finances, which in turn forced the Province to step by imposing structural austerities on the City of about EUR 8-10 million annually in order to solve its deficit by 2022. The Municipal Executive Board eventually resigned, and Apeldoorn put its land banking activities on hold (Gemeente Apeldoorn, 2013), in order to protect municipal finance from financialized real estate markets.

The City of Apeldoorn's model of financialized urban governance, which tied the fate of the City to the rhythm of the real estate market, had failed. But in contrast to failed financialized cities in the US, an extensive inter-municipal financial solidarity system supervised by central state agencies and financed by state bank BNG "ringfenced" (Allen and Pryke, 2013) municipalities from interaction with "predatory finance" (Peck and Whiteside, 2016). BNG continues to lend to the City at the same low interest rates as it does to other municipalities, and most of the municipal budget still contributes towards managerial tasks (Gemeente Apeldoorn, 2016). Nevertheless, 
Figure 1 Important developments on Apeldoorn's financial balance sheet (x 1,000 euro)

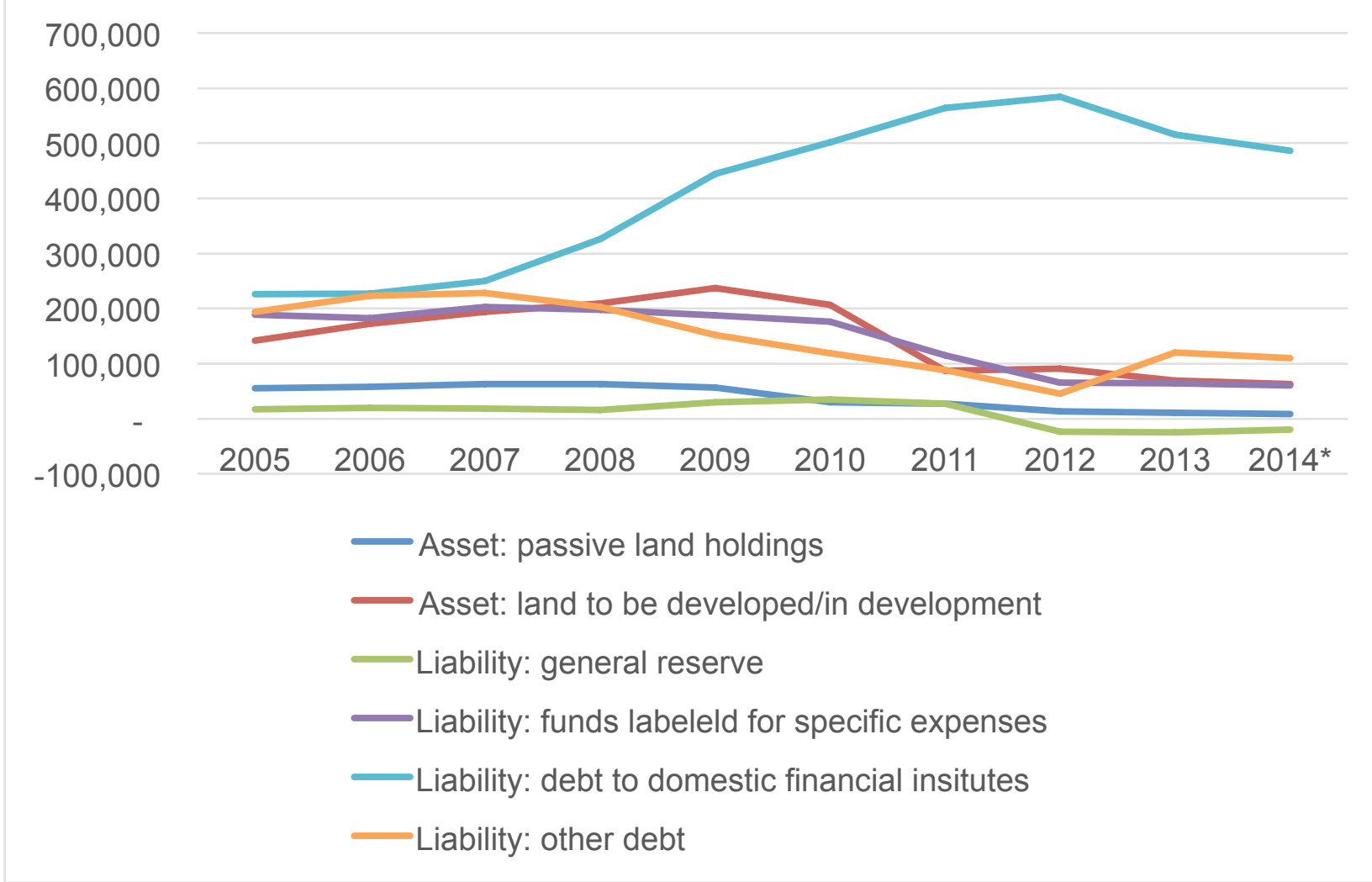

in line with practices elsewhere (Aalbers et al., 2017; Ashton et al., 2016) the losses of Apeldoorn's highly speculative municipal entrepreneurialism were socialized through structural austerities on basic municipal services. In contrast to the US, financialization in the Dutch context does not relate to the increased dominance of financial actors but to the interplay between local politicians and civil servants, on the one hand, and landowners and private developers, on the other. In the Dutch case financialized practices offer opportunities for higher profits that could then be reinvested into entrepreneurial projects. Land banks, like the one in Apeldoorn, are primarily steered by the Municipal Executive Board (especially the Alderman of Urban Planning) and municipal managers with a highly entrepreneurial spirit. As a result, we witness a shift in urban planning from a means to provide public goods to a tool to extract financial profits for municipalities. Land banks, once a key instrument of Dutch managerial urban planning and governance, were transformed into financialized actors and instruments to realize entrepreneurial municipal goals.

\section{The entrepreneuralization of Flemish urban development}

\section{An entrepreneurial stance towards urban (re-)development}

Although Belgium (Flanders) and Netherlands can be situated in the same corporate welfare tradition, in the field of housing and urban and spatial planning they are substantially different. For more than a century, housing policies in Belgium have been geared towards promoting private homeownership in general and self-provision or "auto-construction" of houses in particular (cf. De Decker et al., 2005). This housing 
preference was (and to an extent still is) supported by a weak urban planning policy that provided construction land as "an abundant consumable commodity" (Franzen and Halleux, 2004: 53) and a legitimate source of profit for landowners (often farmers). The location of activities was hardly the subject of policy clarifications or intense public debate, meaning that functions were allocated largely through the market and did not reflect concerns about what constitutes "good" planning practice. House prices followed an economic model based on a vast supply of land: the further away from the urban centre the cheaper the land became, resulting into a lot of "spatial waste", inefficiency, congestion and urban flight (Halleux et al., 2012). The long-time absence of any central state-led urban policy led to the worsening of persistent urban problems. Consequently, in Belgium - at least as far as housing and urban and spatial planning are concerned - there is only a weak managerial and welfare tradition.

Going against international tendencies towards urban entrepreneurialism, this historical laissez-faire mode of suburban development ${ }^{1}$ was challenged by the development of "spatial structure planning" in the 1990s, which aimed to protect open space and locate new housing and other development mainly in towns and cities, combined with the gradual development of (social) urban policies from the 1980s onwards (De Decker et al., 2005). In the 1990s, Flemish urban policy took the form of territorial welfare policies in disadvantaged neighbourhoods (Moulaert and Nussbaumer, 2005). Despite this late and rather modest move towards welfare traditions in planning and housing policy, around the year 2000 Flemish urban policies started to shift towards a more entrepreneurial approach, focusing on "opportunities" rather than "problems" (Loopmans, 2007: 215). The allocation of financial resources is no longer based on the level of social problems but on population numbers. Local public welfare centres lost their central role, and the volume of resources dedicated to public services and the poor dropped significantly (Loopmans, 2004). Instead, attracting middle class residents to the city and improving "spatial quality" became the focus of Flemish urban policies.

In the context of this shift towards entrepreneurialism, two policy instruments are important (cf. Taşan-Kok, 2010). First, the 2003 Public Private Partnership Decree, which created a regulatory framework for PPP projects in the policy domains for which the Flemish government is responsible and the 2002 Decree, which made Flemish government financial support for urban renewal projects conditional on $30 \%$ private funding. Second, in 1995 (and further expanded in the Municipality Decree of 2005) municipalities were given the opportunity to set up autonomous municipal corporations (Autonome Gemeentebedrijven, hereafter AG). AGs are legally separate entities (with the municipality as sole shareholder) that can operate more flexibly than the city administration (e.g., spending money, recruiting personnel, etc.) and often acts at some distance of the democratic control of the City Council. Also, the consolidated balance sheets of AGs are excluded from supra-local supervision (Leroy, 2015). Most AGs deploy activities related to real estate (VVSG, 2017) and play a key role in larger urban real estate (re)developments. They advise the urban planning agency and function as real estate developers, by actively buying land/properties and (re)developing new properties or by participating, often with various other semi-state agencies, in PPP projects (Loopmans, 2008; Taşan-Kok, 2010).

\footnotetext{
${ }^{1}$ We prefer not to call this neoliberalism, since we see neoliberalism as a response to welfare regimes, with the aim to roll back welfare institutions. The weak development of welfare institutions in the field of housing and urban and spatial planning are better described as a liberal laissez-faire model.
} 
Both PPP constructions and municipal real estate corporations have moved the decision-making process around urban development into a new, multi-actor and multiscalar - and therefore less transparent - institutional setting, increasing the power of a selective group of (semi-)private actors (primarily developers, investors and landowners) and the executive side of the political sphere (primarily mayors, aldermen, engineers, ministers). Although power constellations differ from project to project, in general, it means that urban development is managed by a technocratic elite that tends to focus more on competing for investments and well-off sections of the population, thereby becoming increasingly detached from the needs and preferences of large sections of the urban population (Block et al., 2012; Van Den Broeck, 2011; Debruyne et al., 2008). However, this process is geographically variegated; in larger Flemish cities, with a more profound history of social innovation, urban projects often still have meaningful social components (Loopmans, 2007).

This section indicates that in larger Flemish cities in particular a wide range of entrepreneurial tools is available to local politicians to steer urban (re)development, with the autonomous real estate corporation (AG) as the crucial instrument. But, it is unclear whether and how these entities connect municipal finance with local real estate markets. The next section tries to shed light on these connections by analysing one of the largest AGs: AG Vespa in Antwerp.

\section{A municipal instrument to steer urban development: AG Vespa}

Antwerp is the second largest city of Belgium (approximately 520,000 residents). The origination of Flemish urban policy and related funding streams in the 1980s and 1990s was welcomed by Antwerp, as it struggled with both persistent urban problems and high levels of debt that resulted in the continuous implementation of structural austerity policies. The European Union fund Urban I, which started in 1995, created an important "turning moment" towards more entrepreneurial urban development strategies (Novy et al., 2013). The EU forced state agencies into cooperation and professionalization, as it demanded an integrated approach towards neighbourhood revitalization and realization of urban projects within a relative brief time horizon. To realise these goals the City set up new municipal urban planning entities such as SOMA (Stadsontwikkelingsmaatschappij Antwerpen) and the Planningscel, which would pave the way for the establishment of the crucial municipal instruments for urban (re)development: AG Vespa in 2003 and AG Stadsplanning in 2009 (Van Den Broeck et al., 2015).

Until 2003 "[public] money was the engine of large urban development projects" (Interview 5), and the use of vehicles such as SOMA for the management of supralocal funding and the implementation of urban projects gave the Municipal Executive Board a lot of control over the governance of urban development. There was widespread consensus among both local government and urban planners that social goals should be the central focus, and funds primarily went to disadvantaged neighbourhoods. The institutional capacity that supported the turn towards an entrepreneurial form of governance was developed to pursue explicitly social urban renewal aims, but, as we will show below, in the 2000s it became the vehicle for fullfledged urban entrepreneurialism.

In 2003, the new social-democratic mayor Janssens made urban development the central focus of his policy programme, in an attempt to restore the pride of city 
residents, which had been undermined by two decades of negative discourses vigorously disseminated by the extreme-right party Vlaams Blok (Van Den Broeck et al., 2015), and attract a "more vital population" (Anciaux in Loopmans et al., 2010: 193), which refers to the competition with suburban areas for middle class residents. In order to do so, he avoided the big ideological debates that had polarized the Antwerp City Council and population for so long and adopted a pragmatic approach to urban governance - "getting things done" (Van Den Broeck et al., 2015). Supported by changes in supra-local urban policy, i.e. the aforementioned decrees encouraging PPP, and in supra-local funding, i.e. the shift from the more social urban renewal funding towards the more spatial development-oriented City Fund, the governance of urban development acquired more overt entrepreneurial characteristics, both in its aims and means. Testimony to this shift are the intensive use of city marketing campaigns, the adoption of a new public management approach (here referring to the adoption of private sector governance techniques) to urban governance (in response to the presumed ideological divisions "of the past"), the persistent stress on urban opportunities, and the role of the middle class in revitalising the city. Rather than focusing on urban social problems, the hiring of highly educated urban professionals to work on strategic urban projects and the (further) development of autonomous municipal corporations such as AG Vespa and AG Stadsplanning came to the fore. Still, this entrepreneurial approach was mixed with social-democratic elements, notably the important role of AG Stadsplanning and the City Architect (stadsbouwmeester) in balancing spatial quality and public interest considerations with the profitability concerns of real estate projects as well as the deliberate and strategic development of "land positions" by Vespa, aimed at increasing public negotiation power (Van Den Broeck et al., 2015). The latter reflects the rather late turn towards welfare concerns in spatial and urban planning (although often mixed up with middle class-oriented interpretations of spatial quality), resulting in a locally specific variety of urban entrepreneurialism.

When the social-democratic mayor Janssens lost the 2012 elections and a new right-wing city council was established, it was precisely the institutions playing this balancing role that were targeted. The new responsible alderman preferred direct, close and supportive relationships with private real estate developers and questioned the welfare role of urban planning in embedding private real estate interests and actions in public policy strategies. The City Architect quit his job because of diverging visions and lack of cooperation, and the strategic urban planning unit AG Stadsplanning, which had focused on spatial quality, was closed and most of its staff was integrated into the autonomous municipal real estate company AG Vespa. According to several interviewees, this moved the decision-making process on urban development into the "backrooms" and privileged private real estate interests:

In the past, the private contribution to public space was first negotiated by AG Vespa/AG Stadsplanning and then accepted by politicians. Nowadays, these negotiations take place between private developers and politicians in restaurants. So, that is a different procedure in which private interests are more powerful. On the other hand, private actors also help to bring back private capital into the city. It is another question whether the projects they finance benefit the city. (Interview BE5)

The remainder of this section sheds light on how AG Vespa is connected to municipal finance and Antwerp's real estate market by discussing AG Vespa's history and crucial financial elements displayed in figures 2 and 3. 
Figure 2 AG Vespa Crucial income and expenditures (in million euro)

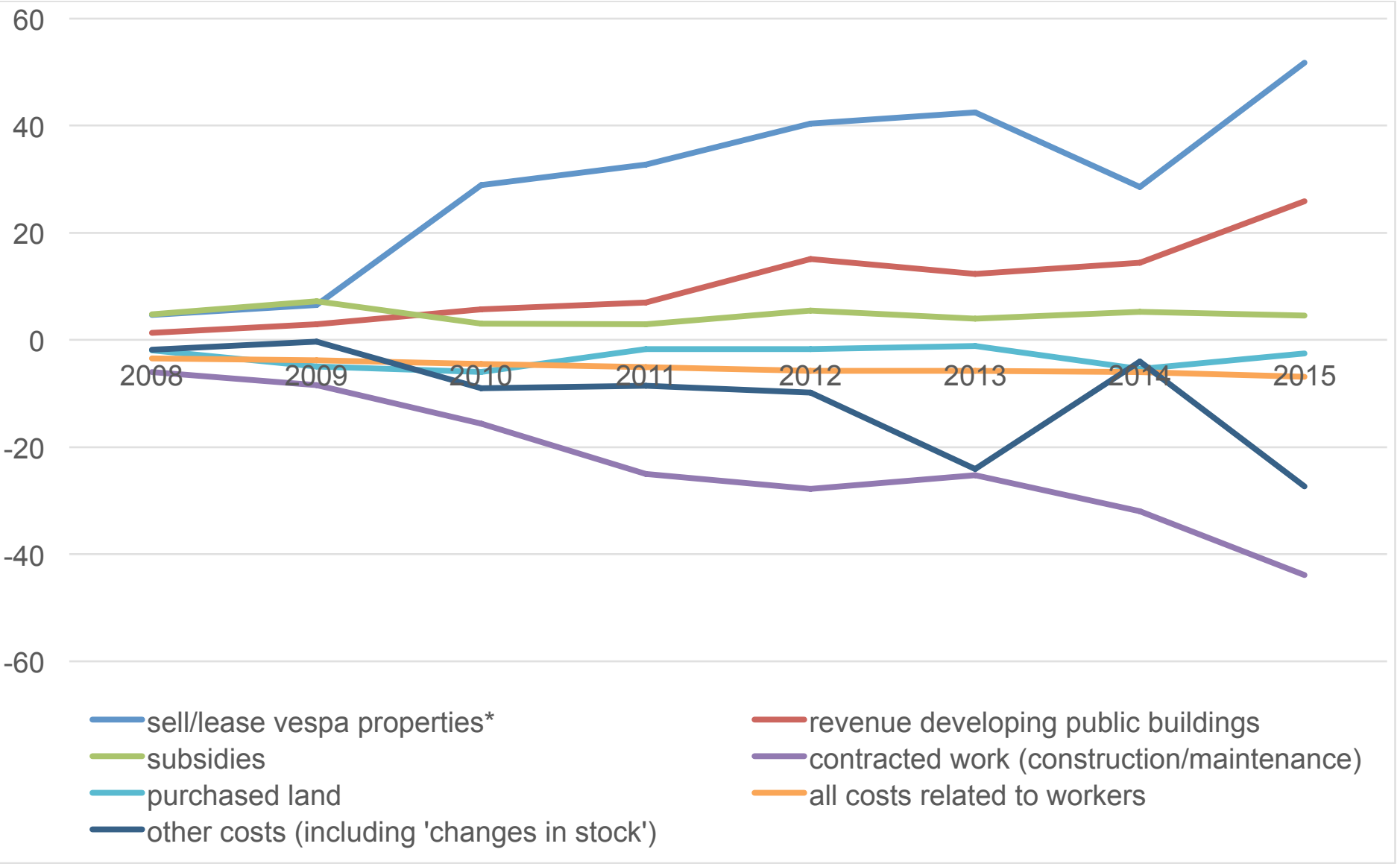

Source; Annual Reports AG Vespa

Figure 3 AG Vespa's largest assets and liabilities (in million euro)

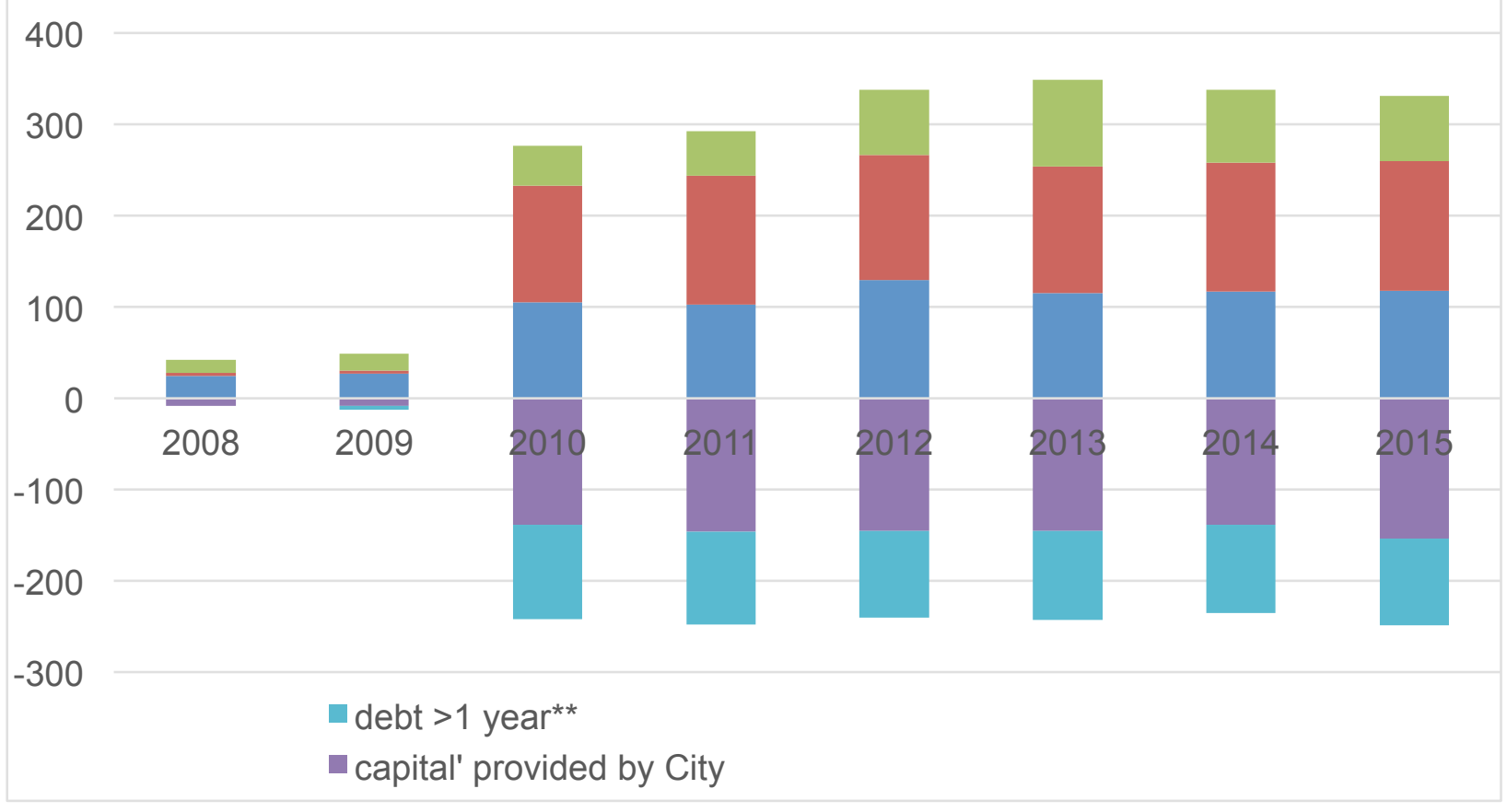

Source; Annual Reports AG Vespa 
Under the integrated approach required under the urban programmes, actively buying, (re)developing and selling properties was extremely difficult within the regular City administration (Interviews). In 1992, the city council established the non-profit association SOMA to manage supra-local funds, implement urban projects and buy properties. In 2003, SOMA was abolished and part of it was merged with the city's Office of Patrimony and Real Estate to form AG Vespa. One of its important tasks was to actively (re)develop residential units (398, between 2003 and 2013) and public buildings (17 in the same period) in deprived neighbourhoods, comprising the bulk of AG Vespa income and expenses (see figure 2). The aim was to upgrade specific key properties through high-quality architecture and to sell them (often at a loss) to highincome groups to upgrade disadvantaged neighbourhoods (Loopmans, 2008), through so-called urban acupuncture (De Ridder, 2015: 45).

AG Vespa concentrated the municipal real estate expertise within a professional organization to smoothen the urban planning process, making it more attractive for private actors to participate in urban development (Taşan-Kok, 2010). Because of its separate legal status as an autonomous municipal company, it does not have to obey civil servant labour contracts, enabling a more flexible recruitment policy. It also allowed AGs "to pursue the goals of the organization rather than the City Council agreement" (Interview 3). In this respect, especially the transfer of municipal properties, the related loan and the valuation of these properties put AG Vespa in a more powerful position.

The use of autonomous municipal companies enables municipalities to become active on land markets. AG Vespa bought EUR 25.5 million of land for development projects in the 2008-2015 period (see figure 2). Still, land holdings are relatively small compared to the large property portfolio of AG Vespa, as in 2010 (see figure 3) the municipality transferred many properties to the AG with the specific aim to "activate and optimize the City's real estate portfolio by improving letting conditions or improving sales revenues and speeding up both processes as the City needed money for its austerities" (Interview BE1, manager at the financial department of the City of Antwerp). The properties were valued at EUR 129 million by AG Vespa (AG Vespa, 2011), but the valuation "took place on the basis of rough estimations: one estimation was more detailed than the other ... but, for other properties, we have to conclude that they miss-estimated the values" (Interview BE3). The transfer included a special loan of EUR 100 million that had to be repaid from income generated through property sales. The transfer also required a minimum pay-out of AG Vespa to the City of Antwerp, set at EUR 8-10 million annually between 2010 and 2014, and at EUR 4.5 million from 2015 onwards - much lower than the realised income from rental/sale (see figure 3).

As figure 3 illustrates, this transfer created a sizeable balance sheet increasing the power of AG Vespa vis-à-vis private real estate actors but also within the City of Antwerp. It made the City more vulnerable to downturns in Antwerp's real estate market, for instance, when projected sales prices would be lower than expected. However, in contrast to the Netherlands, Belgian real estate prices have increased steadily since the 1990s (Van Loon, 2017). Moreover, continuously rising real estate prices masked the lack of a sophisticated framework to protect Antwerp's municipal finance from real estate market risks. Nevertheless, most liabilities (see figure 3) consist of internal loans/capital provision to optimize fiscal arrangements between AG Vespa and the City. On the asset side, the treasury is invested in a mixture of deposits, bonds and saving accounts, creating some financial risks. 


\section{Discussion and Conclusion}

It would be a mistake to ignore that a large part of what municipal governments in the Netherlands and Flanders are doing today still revolves around public service provision in the tradition of urban managerialism (cf. Engelen et al., 2016). However, looking at a policy domain in which municipalities in both countries have considerable influence, namely urban development, this paper shows that while the dominant paradigms on globalization, European integration and financialization suggest that cities become increasingly dependent on global capitalism, Flemish and Dutch cities mostly adopted pro-growth policies with the aim of attracting primarily domestic flows of investments and more well-off sections of the population. In this pursuit, Dutch municipalities were ring-fenced through national regulation that prohibited financing their growing real estate ambitions through global capital markets. Flemish municipalities experienced fewer restrictions to interact with global finance; however, the autonomous municipal real estate corporations are closely interwoven with local budgets and primarily use supra-local government funds for funding.

Consequently, direct influence by financial actors on urban governance is largely absent in both countries. Nevertheless, crucial municipal instruments were invented - in the Dutch case, reinvented - to move the decision-making process around urban development into the realm of semi-public and private actors that prioritized entrepreneurial goals over the provision of public goods. The integration of these instruments, the Dutch municipal land banks and the Flemish municipal real estate corporations, can be seen as the systematic local reproduction of neoliberal urban policy tools that prioritize more market-oriented solutions. The active use of these neoliberal urban development policy instruments turns municipalities into active players on local real estate markets, thereby connecting the risks of financialized real estate markets to municipal finance. As considerable parts of municipal budgets have become allocated to investments in local real estate markets (see figures 1 to 3 ), real estate risks can become excessive because these organizations have a bureaucratic perspective that neglects essential features of real estate markets, for instance, lacking a sophisticated risk management strategy.

Analysing the specificity of both cases enables us to discuss two variegated, European forms of financialized and entrepreneurial urban governance around urban development. Dutch urban governance around urban development has experienced similar stimuli to financialize as in the United States, such as debt-fuelled real estate bubbles and a discourse emphasizing the exchange value of land. However, and crucially different, as Dutch municipalities are to a high degree ring-fenced from interaction with financial actors, wholesale US-style financialization of urban governance has been impossible. Also, enduring institutional frameworks based on inter-municipal financial solidarity still offer an "infrastructural baseline that mitigate[s] the sharpest edges of uneven development" (Kirkpatrick, 2016: 48).

Nevertheless, Dutch municipalities adopted an urban development model in which they used municipal land banks to purchase large land holdings and their planning authorities to re-zone especially agricultural land into more profitable uses. In the Netherlands, a managerial instrument - the land bank - was turned into a financialized instrument of entrepreneurial urban growth policies. Indeed, financialized urbanism is not a new phase of (or following) entrepreneurial urbanism, but rather the means through which entrepreneurial urbanism was enabled in the first place. Consequently, instead of tempering the euphoria within real estate markets, state 
Table 2 Variegated municipal instruments for steering urban development

\begin{tabular}{|c|c|c|}
\hline Characteristics & Antwerp & Apeldoorn \\
\hline $\begin{array}{l}\text { Municipal expertise in real } \\
\text { estate markets/finance }\end{array}$ & low & low \\
\hline Name of instrument & $\begin{array}{c}\text { AG Vespa } \\
\text { (autonomous municipal } \\
\text { corporation) }\end{array}$ & $\begin{array}{c}\text { Grondbedrijf } \\
\text { (municipal land bank) }\end{array}$ \\
\hline $\begin{array}{l}\text { Debt related to municipal real } \\
\text { estate activities }\end{array}$ & (very) low & high \\
\hline $\begin{array}{l}\text { Supra-local supervision of } \\
\text { instrument }\end{array}$ & low & low \\
\hline $\begin{array}{l}\text { Power of Municipal Executive } \\
\text { Board on instrument }\end{array}$ & high & high \\
\hline $\begin{array}{l}\text { Democratic control through } \\
\text { City Council }\end{array}$ & low & low \\
\hline $\begin{array}{l}\text { Openness to cooperate with } \\
\text { private real estate actors }\end{array}$ & high & high \\
\hline $\begin{array}{l}\text { Obligatory contribution to } \\
\text { general municipal finances }\end{array}$ & $\begin{array}{l}\text { - Yes, but } \\
\text { considerably lower } \\
\text { than total real estate } \\
\text { revenues } \\
\text { - No pressure to } \\
\text { increase profits }\end{array}$ & $\begin{array}{l}\text { - Yes, first in line with } \\
\text { real estate revenues; } \\
\text { later higher than } \\
\text { revenues } \\
\text { - Pressure to increase } \\
\text { profits }\end{array}$ \\
\hline Internal loans to entity & Considerable & $\begin{array}{l}\text { Considerable, with } \\
\text { interest margins for } \\
\text { general municipal budget }\end{array}$ \\
\hline Main activities & $\begin{array}{l}\text { - Asset management } \\
\text { - Project management } \\
\text { - Urban acupuncture }\end{array}$ & $\begin{array}{l}\text { - Land speculation } \\
\text { - Urban planning } \\
\text { - Profit-generation to } \\
\text { fund prestige projects }\end{array}$ \\
\hline Risk management system & Absent & $\begin{array}{c}\text { Only created after major } \\
\text { losses in } 2010\end{array}$ \\
\hline Local real estate prices & Continuously rising & $\begin{array}{l}\text { Rising until } 2010 \text {, then } \\
\text { decreasing }\end{array}$ \\
\hline \multirow{3}{*}{ Shared outcomes } & \multicolumn{2}{|c|}{$\begin{array}{c}\text { Instruments connect municipal finance to local rea } \\
\text { estate markets and enable profits (and losses) } \\
\text { from rising (and falling) real estate prices }\end{array}$} \\
\hline & \multicolumn{2}{|c|}{$\begin{array}{c}\text { Instruments open up possibilities for closer } \\
\text { cooperation with private actors }\end{array}$} \\
\hline & \multicolumn{2}{|c|}{$\begin{array}{l}\text { Instruments create a realm for bureaucratic } \\
\text { calculative practices related to real estate finance }\end{array}$} \\
\hline
\end{tabular}


agencies have made rising land and real estate prices a policy priority. (Semi-)public and private actors have collectively embraced an economic growth model based on excessive real estate debt creation in which the production of new real estate was a crucial element. Once the Dutch real estate bubble burst, the most speculative municipalities had to implement rigid austerity policies to balance their budgets. The costs of land speculation by highly entrepreneurial municipal land banks were socialized through structural austerities on basic local public services. Nonetheless, cheap finance from a state bank and supervision from supra-local state agencies sheltered municipalities from bankruptcy.

The Netherlands offers empirical evidence of a European variegation of the financialization of urban governance related to urban (re)development. In line with the Spanish case (Coq-Huelva, 2013), financializing European urban governance is about pro-growth local governments actively adopting bureaucratic calculative practices and planning overly optimistically to profit from financialized real estate markets. The situation is different from the United States, where financial actors capture urban governance. Consequently, the research agenda should not be as Peck and Whiteside (2016: 4) suggest, to research how financial actors through "intermediation, instrumentalization, institutionalization and intensification" capture urban governance. Instead, European, and perhaps also other, studies on the financialization of urban governance should revolve around the ways in which municipalities use specific instruments and related calculative practices to connect their finances to financialized real estate markets (cf. Ashton et al., 2016).

Flemish municipalities, with a long history of financial autonomy and a lax attitude towards urban planning, turned private landowners and construction firms into the prime producers of ever expanding sprawl. Only in the late 1980s and 1990s, a modest turn towards welfare modes of urban and spatial planning took place, aiming to embed private real estate interests and strategies into public policy concerns with spatial quality. Consequently, the rise of more entrepreneurial modes of urban development in the 1990s has a very ambiguous character, with the first wave of state-supported urban (re)development being entrepreneurial in form but distinctively social in nature (Christiaens et al., 2007; Moulaert and Nussbaumer, 2005).

From the late 1990s onwards the governance of urban development in Antwerp took a more entrepreneurial turn and built further on the institutional legacy of the previous period of social urban renewal. Urban institutions originally established to manage supra-local funds and to provide the executive part of the local government with more autonomy to develop and implement strategic urban projects were turned into autonomous municipal real estate corporations in the early 2000s. In larger cities they became crucial vehicles for steering urban (re)development. Combined with PPP constructions this development not only connected municipal finance closely with local real estate markets, but also moved the decision-making process away from the democratic control of elected City Councils. Still, at least during the period of socialdemocratic rule, several institutions remained in place, most notably the autonomous municipal company AG Stadsplanning and the City Architect. They served to balance private and public real estate interests with the wider public interest, especially in relation to "spatial quality". As Flemish real estate values have enjoyed a continuous upward trend since the early 1990s, it is difficult to see excessive risk-taking place. However, elements such as sophisticated risk management and basic information about valuation and market developments are still largely absent in these autonomous municipal corporations. 
Flemish entrepreneurialism partially resembles practices observed in the United States during the 1980s and 1990s, with similar growth coalitions and opaqueness around decision-making procedures. This finding opens up future investigations into the temporality of dominant trends within urban governance elsewhere in Europe: why did the US model, and to a lesser extent the Dutch model, evolve from an entrepreneurial mode into a financialized mode, while in Flanders entrepreneurialism remains dominant? Furthermore, we need to understand how instruments developed under managerial rule, such as the Dutch municipal land banks, or developed to take a managerial turn in a largely laissez-faire model, such as the Flemish autonomous municipal corporations, can be turned into either a financialized vehicle that enables entrepreneurial urbanism (Netherlands) or a more straightforward instrument of entrepreneurial urbanism (Flanders).

\section{References}

Aalbers, MB (eds) (2012) Subprime Cities The Political Economy of Mortgage Markets, Oxford, Willey-Blackwell.

Aalbers MB (2013) Debate on Neoliberalism in and after the Neoliberal Crisis. International Journal of Urban and Regional Research, 37(3): 1053-1057.

Aalbers MB (2017a) Corporate Financialization. In Richardson D, Castree C, Goodchild MF, Kobayashi AL and Marston R (eds) The International Encyclopedia of Geography: People, the Earth, Environment, and Technology, Oxford, Wiley.

Aalbers MB (2017b) The pre-histories of neoliberal urbanism in the United States. In: Pinson G and Journel CM (eds) Debating the Neoliberal City. London: Routledge, 96-118.

Aalbers MB, Van Loon J and Fernandez R (2017) The Financialization of a Social Housing Provider. International Journal of Urban and Regional Research 41(4): 572-587.

AG VESPA (2011) Vastgoeddochter van de Stad. Available at: http://www.agvespa.be/nieuws/vooruitgangsrapport-2010

Allen J and Pryke M (2013) Financialising Household Water: Thames Water, MEIF, and " Ring-Fenced " Politics. Cambridge Journal of Regions, Economy and Society 6(3): 419439.

Ashton P, Doussard M and Weber R (2016) Reconstituting the State: City Powers and Exposures in Chicago's Infrastructure Leases. Urban Studies 53(7): 1384-1400.

Block T, Steyvers K, Oosterlynck, S, et al. (2012) When Strategic Plans Fail to Lead. A Complexity Acknowledging Perspective on Decision-Making in Urban Development Projects-The Case of Kortrijk (Belgium). European Planning Studies 20(6): 981-997.

Brenner N (2004) Urban Governance and the Production of New State Spaces in Western Europe, 1960-2000. Review of International Political Economy 11(3): 447-488.

Brenner N, Peck, J and Theodore N (2010) Variegated Neoliberalization: Geographies, Modalities, Pathways. Global Networks 10(2): 182-222.

Brenner N and Theodore N (2002) Cities and the Geographies of "Actually Existing Neoliberalism". Antipode 34(3): 350-379.

Broeck J Van Den, Vermeulen P, Oosterlynck S, et al. (2015) Antwerpen, Herwonnen Stad? Anwerp: Die Keure. 
Broeck P Van Den (2011) Limits to Social Innovation. Shifts in Flemish Strategic Projects towards Market Oriented Approaches. Belgeo 1(2): 75-88.

Buitelaar E and Bregman A (2016) Dutch Land Development Institutions in the Face of Crisis: Trembling Pillars in the Planners' Paradise. European Planning Studies 24(7): 12811294.

Christiaens E Moulaert F and Bosmans B (2007) The End of Social Innovation in Urban Development Strategies?: The Case of Antwerp and the Neighbourhood Development Association ‘Bom'. European Urban and Regional Studies 14(3): 238-251.

Coq-Huelva D (2013) Urbanisation and Financialisation in the Context of a Rescaling State: The Case of Spain. Antipode 45(5): 1213-1231.

Cox KR (2010) The Problem of Metropolitan Governance and the Politics of Scale. Regional Studies 44: 215-227.

Crouch C and Le Galès P (2012) Cities as National Champions? Journal of European Public Policy 19(3): 405-419.

Debruyne P, Oosterlynck S and Block T (2008) Sociale Innovatie Als Basis Voor Stadsontwikkeling? Grootschalige Stadsprojecten versus Sociale Stadsvernieuwing in Gent. Ruimte en Planning, 3, 18-33.

De Decker P, Kesteloot, C., De Maesschalck, F. and Vranken, J. (2005) 'Revitalizing the City in an Anti-Urban Context: Extreme Right and the Rise of Urban Policies in Flanders, Belgium'. International Journal of Urban and Regional Research 29(1): 152-171.

Doucet B (2013) Variations of the Entrepreneurial City: Goals, Roles and Visions in Rotterdam's Kop van Zuid and the Glasgow Harbour Megaprojects. International Journal of Urban and Regional Research 37(6): 2035-2051.

Engelen EE, Froud J, Johal S, et al. (2016) How Cities Work: A Policy Agenda for the Grounded City. CRESC Working Paper Series 141: 1-31.

Enquetecommissie Grondbedrijf (2012) De Grond Wordt Duur Betaald: Raadsonderzoek Naar Het Grondbedrijf in de Gemeente Apeldoorn. Den Haag: Opmeer Drukkerij BV.

Epsing-Andersen G (1990) The three worlds of welfare capitalism. Oxford: Wiley.

Flyvbjerg B (2006) Five Misunderstandings About Case-Study Research. Qualitative Inquiry 12: 219-245.

Franzen MF and Halleux JM (2004) European Cities: Dynamics Insights on Outskirts.

Le Galès P (2016) Neoliberalism and Urban Change: Stretching a Good Idea Too Far? Territory, Politics, Governance 4: 154-172.

Gemeente Apeldoorn (2001) Strategische Economische Beleidsvisie Apeldoorn 2000-2020: Apeldoorn Economisch Aantrekkelijk.

Gemeente Apeldoorn (2013) Nota Grondbeleid 2013 Versteviging van fundamenten onder turbulente omstandigheden. Apeldoorn: Gemeente Apeldoorn.

Gemeente Apeldoorn (2016) Jaarstukken 2015. Accessed at: www.apeldoorn.nl/ter/politiekenorganisatie/Beleid-en-financien/Beleid-en-financienJaarverslag.html

Gerring J (2007) Case Study Research: Principles and Practices. Cambridge, Cambridge University Press.

Gonzalez S and Oosterlynck S (2014) Crisis and Resilience in a Finance-Led City: Effects of the Global Financial Crisis in Leeds. Urban Studies 51(15): 3164-3179.

Guironnet A, Attuyer K and Halbert L (2016) Building Cities on Financial Assets: The Financialisation of Property Markets and Its Implications for City Governments in the Paris City-Region. Urban Studies 53(7): 1442-1464.

Hajer M and Zonneveld W (2000) Urban planning in the Network Society-Rethinking the 
Principles of Planning in the Netherlands. European Planning Studies 8(3): 337-355.

Halbert L, Henneberry J and Mouzakis F (2014) Finance, Business Property and Urban and Regional Development. Regional Studies 48(3): 421-424.

Hall T and Hubbard P (1996) The Entrepreneurial City: New Urban Politics, New Urban Geographies? Progress in Human Geography 20(2): 153-174.

Halleux JM, Marcinczak S and Van Der Krabben E (2012) The Adaptive Efficiency of Land Use Planning Measured by the Control of Urban Sprawl. The Cases of the Netherlands, Belgium and Poland. Land Use Policy 29(4): 887-898.

Harvey D (1978) The Urban Process under Capitalism: A Framework for Analysis. International Journal of Urban and Regional Research 2(1-4): 101-131.

Harvey D (1989) From Managerialism to Entrepreneurialism: The Transformation in Urban Governance in Late Capitalism. Geografiska Annaler. Series B, Human Geography 71(1): 3-17.

Haughton G, Allmendinger P and Oosterlynck S (2013) Spaces of Neoliberal Experimentation: Soft Spaces, Postpolitics, and Neoliberal Governmentality. Environment and Planning A 45(1): 217-234.

Janssen-Jansen L, Peel D and Krabben E Van Der (2012) Planning in an Environment without Growth. Den Haag, Rli.

Kirkpatrick LO (2016) The New Urban Fiscal Crisis: Finance, Democracy, and Municipal Debt. Politics \& Society 44(1): 45-80.

Krabben E Van Der and Jacobs HM (2013) Public Land Development as a Strategic Tool for Redevelopment: Reflections on the Dutch Experience. Land Use Policy 30(1): 774-783.

Lauermann J (2016) Municipal statecraft: Revisiting the geographies of the entrepreneurial city. Progress in Human Geography 00: 1-20 (accessed 9 March 2017)

Leroy J (2015) Kredietwaardigheid van Vlaamse Gemeenten en OCMW's. Brussel: VVSG.

Loon J Van (2016) Patient versus Impatient Capital: The (Non-)Financialization of Real Estate Developers in the Low Countries. Socio-Economic Review 14(4): 709-728.

Loon J Van (2017) The (non-)financialization of urban development in the Low Countries. Leuven: KU Leuven, PhD Disseration.

Loopmans MPJ (2004) Tu quoque, Marino? Evaluatie van en vooruitblik op het Stedenfonds. Ruimte \& Planning 24(4): 13.

Loopmans MPJ (2008) Relevance, Gentrification and the Development of a New Hegemony on Urban Policies in Antwerp, Belgium. Urban Studies 45(12): 2499-2519.

Loopmans MPJ (2007) From SIF to City Fund: A New Direction for Urban Policy in Flanders, Belgium. Journal of Housing and the Built Environment 22(2): 215-225.

Loopmans MPJ, Decker P De and Kesteloot C (2010) Social Mix and Passive Revolution. A Neo-Gramscian Analysis of the Social Mix Rhetoric in Flanders , Belgium. Housing Studies 25(2): 181-200.

Moulaert F and Nussbaumer J (2005) Defining the Social Economy and Its Governance at the Neighbourhood Level: A Methodological Reflection. Urban Studies 42(11): 2071-2088.

Novy A, Mehmood A and Moulaert F (2013) The DEMOLOGOS Methodology for Analysing Urban and Regional Trajectories. In: Martinelli F, Moulaert F and Novy A (eds) Urban and Regional Development Trajectories in Contemporary Capitalism. New York: Routledge, 45-62.

Oosterlynck S (2010) Regulating Regional Uneven Development and the Politics of Reconfiguring Belgian State Space. Antipode 42(5): 1151-1179.

Oosterlynck S and Swyngedouw E (2010) Noise Reduction: The Postpolitical Quandary of Night Flights at Brussels Airport. Environment and Planning A 42(5): 1577-1594. 
Peck J (2004) Geography and Public Policy: Constructions of Neoliberalism. Progress in Human Geography 28: 392-405.

Peck J and Tickell A (2002) Neoliberalizing Space. Antipode 34: 380-404.

Peck, J. and Whiteside, H. (2016) Financializing Detroit. Economic Geography 92(3): 235-286.

Pinson G and CM Journel (2016) The Neoliberal City - Theory, Evidence, Debates. Territory, Politics, Governance 4(2): 137-153.

RFV (2015) Grond, Geld En Gemeenten. Accessed at: www.robrfv.nl/documenten/grond_geld_en_gemeenten.pdf

Ridder R De (2015) Hoe woont een samenleving in verandering? Stadsontwikkeling volgens AG VESPA en sogent. Architraaf 185: 44-47.

Robinson J (2015) Thinking Cities through Elsewhere: Comparative Tactics for a More Global Urban Studies. Progress in Human Geography 40: 3-29.

Sassen S (2013) Before Method: Analytic Tactics to Decipher the Global-An Argument and Its Responses, Part I. The Pluralist 8: 79-82.

Savini F and Aalbers MB (2016) The de-Contextualisation of Land Use Planning through Financialisation: Urban Redevelopment in Milan. European Urban and Regional Studies 23(3): 878-894.

Savitch HV and Kantor P (2002) Cities in the International Marketplace: The Political Economy of Urban Development in North America and Western Europe. Princeton: Princeton University Press.

Springer S (2012) Neoliberalism as Discourse: Between Foucauldian Political Economy and Marxian Poststructuralism. Critical Discourse Studies 9: 133-147.

Swyngedouw E (2009) The Antinomies of the Postpolitical City: In Search of a Democratic Politics of Environmental Production. International Journal of Urban and Regional Research 33(3): 601-620.

Swyngedouw E, Moulaert F and Rodriguez A (2002) Neoliberal Urbanization in Europe: LargeScale Urban Development Projects and the New Urban Policy, Antipode 34(3): 542-577.

Taşan-Kok T (2010) Entrepreneurial Governance: Challenges of Large-Scale Property-Led Urban Regeneration Projects. Tijdschrift voor Economische en Sociale Geografie 101(2): 126-149.

Taşan-Kok T and Korthals Altes WK (2012) Rescaling Europe: Effects of Single European Market Regulations on Localized Networks of Governance in Land Development. International Journal of Urban and Regional Research 36(6): 1268-1287.

Theurillat T and Crevoisier O (2013) The Sustainability of a Financialized Urban Megaproject: The Case of Sihlcity in Zurich. International Journal of Urban and Regional Research: 37(6): 2052-2073.

Uitermark J (2005) The Genesis and Evolution of Urban Policy: A Confrontation of Regulationist and Governmentality Approaches. Political Geography 24(2): 137-163.

VVSG (2017) Autonome gemeentebedrijven. Accessed at: www.vvsg.be/Werking_Organisatie/Verzelfstandiging/Autonoom_gemeentebedrijf/Pages/ default.aspx

Vries J De (2015) Planning and Culture Unfolded: The Cases of Flanders and the Netherlands. European Planning Studies 23(11): 1-17.

Weber R (2010) Selling City Futures: The Financialization of Urban Redevelopment Policy. Economic Geography 86(3): 251-274. 


\section{Appendix I}

Interviews Antwerp

Interview 1: Higher management financial department of the City of Antwerp.

Interview 2: Dries Willems, former director AG Stadsplanning and urban planning entities of the City of Antwerp.

Interview 3: Two experienced employees of the financial department of the City of Antwerp.

Interview 4: Jan Leroy, director of the Association of Flemish Cities andMmunicipalities (Vereniging van Vlaamse Steden en Gemeenten), expert on municipal finance.

Interview 5: Griet Geerinck, currently expert on project and municipal finance at AG Vespa (municipal real estate corporation), former director of AG Stadsplanning (municipal urban planning institute).

\section{Interviews Apeldoorn}

Interview 6: Pauline Bieringa, Managing Director Public Finance at BNG Bank \& Robert Bakker, Spokesman BNG Bank.

Interview 7: Maarten Koldewijn, controller of Apeldoorn's Land Bank \& Marco Elshof project economist with Apeldoorn's Land Bank.

Interview 8: Alex Elemans, manager external auditing at the province of Gelderland \& Ben Gesthuizen, financial client manager of Apeldoorn at the Province of Gelderland. 